(6)

\section{OPEN ACCESS}

${ }^{1} S c h o o l$ of Medicine, Oregon Health and Science University, Portland, Oregon, USA

${ }^{2}$ Casey Eye Institute, Oregon Health and Science University, Portland, Oregon, USA

${ }^{3}$ Department of Internal Medicine, Oregon Health and Science University, Portland, Oregon, USA

\section{Correspondence to}

Dr André Martin Mansoor mansooan@ohsu.edu

Accepted 9 February 2017

\title{
Subretinal abscess
}

\author{
Brook Pittenger, ${ }^{1}$ Jonathan W Young, ${ }^{2}$ André Martin Mansoor ${ }^{3}$
}

\section{DESCRIPTION}

A 32-year-old man with a history of intravenous drug use was admitted to the hospital for evaluation of intermittent fever and chills over the course of several weeks. On examination, the temperature was $39.0^{\circ} \mathrm{C}$ and pulse rate $110 \mathrm{bpm}$. A grade $2 / 6$ holosystolic murmur was appreciated at the left lower sternal border. Transthoracic echocardiography with agitated saline contrast demonstrated an echodensity on the septal leaflet of the tricuspid valve associated with mild tricuspid regurgitation and a right-to-left shunt. Blood cultures grew methicillin-resistant Staphylococcus aureus. On the third day of hospitalisation, mild conjunctival erythema of the right eye was observed, which was associated with discomfort and a subjective decrease in vision. Visual fields on confrontation revealed a large inferior scotoma. Bedside indirect ophthalmoscopy established the presence of a yellow, elevated subretinal mass $\sim 10$ times the diameter of the optic disc, adjacent to the superiortemporal vascular arcade, with associated intraretinal haemorrhage (figure 1). These findings were consistent with subretinal abscess. Such abscesses are vision threatening and can progress despite systemic and intraocular antibiotics. Severe cases can lead to retinal detachment and may require surgical intervention, including vitrectomy and retinectomy. In this case, the abscess progressively decreased in size following intravenous vancomycin and intravitreal injections of vancomycin and ceftazidime, with retention of 20/20 vision.

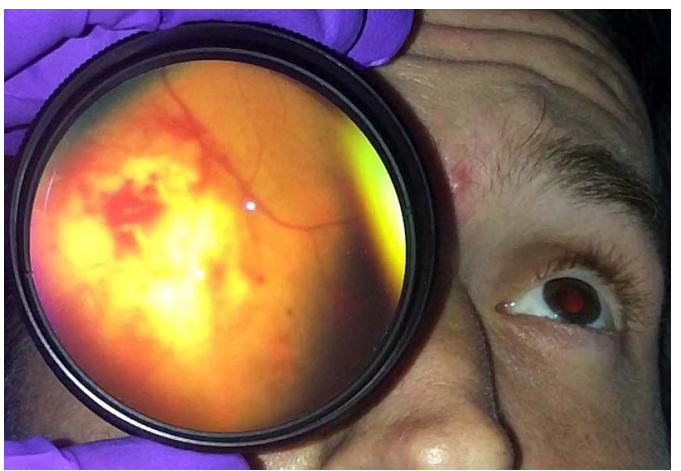

Figure 1 Indirect ophthalmoscopy demonstrating a large subretinal mass and associated intraretinal haemorrhage consistent with subretinal abscess.

\section{Learning points}

Endogenous endophthalmitis, which results from haematogeneous seeding, accounts for $2-8 \%$ of endophthalmitis cases. Subretinal abscess is a rare manifestation of endogenous bacterial endophthalmitis. It should be investigated in patients with risk factors (eg, intravenous drug use, diabetes, immunosuppression and malignancy) who present with loss of vision and vitreoretinal changes. ${ }^{1}$ Early recognition and treatment reduces rates of retinal detachment and improves long-term visual acuity. ${ }^{2}$

- Endocarditis is the underlying source in $~ 10 \%$ of cases of endogenous endophthalmitis. ${ }^{1}$ Tricuspid valve endocarditis is classically associated with septic pulmonary emboli, but paradoxical systemic septic emboli can occur in patients with right-to-left shunt. ${ }^{3}$

- Unilateral subretinal abscess is slightly more common in the right eye than the left, likely due to the proximal anatomy of the brachiocephalic artery providing a preferential embolic pathway. ${ }^{12}$

Contributors JWY captured the clinical image. BP, JWY and AMM were involved in writing the manuscript.

Competing interests None declared.

Patient consent Obtained.

Provenance and peer review Not commissioned; externally pee reviewed.

Open Access This is an Open Access article distributed in accordance with the Creative Commons Attribution Non Commercial (CC BY-NC 4.0) license, which permits others to distribute, remix, adapt, build upon this work non-commercially, and license their derivative works on different terms, provided the original work is properly cited and the use is non-commercial. See: http:// creativecommons.org/licenses/by-nc/4.0/

\section{REFERENCES}

1 Jackson TL, Paraskevopoulos T, Georgalas I. Systematic review of 342 cases of endogenous bacterial endophthalmitis. Surv Ophthalmol 2014;59:627-35.

2 Sadiq M, Hassan M, Agarwal A, et al. Endogenous endophthalmitis: diagnosis, management, and prognosis. J Ophthalmic Inflamm Infect 2015;5:32.

3 Nii T, Yoshikawa H, Okabe T, et al. Septic pulmonary and systemic embolism in tricuspid endocarditis. BMJ Case Rep 2014;2014. 
Copyright 2017 BMJ Publishing Group. All rights reserved. For permission to reuse any of this content visit http://group.bmj.com/group/rights-licensing/permissions.

BMJ Case Report Fellows may re-use this article for personal use and teaching without any further permission.

Become a Fellow of BMJ Case Reports today and you can:

- Submit as many cases as you like

- Enjoy fast sympathetic peer review and rapid publication of accepted articles

- Access all the published articles

- Re-use any of the published material for personal use and teaching without further permission

For information on Institutional Fellowships contact consortiasales@bmjgroup.com

Visit casereports.bmj.com for more articles like this and to become a Fellow 